University of Nebraska - Lincoln

DigitalCommons@University of Nebraska - Lincoln

\title{
Central US earthquake catalog for hazard maps of Memphis,
} Tennessee

Russell L. Wheeler

U.S. Geological Survey, wheeler@usgs.gov

Charles S. Mueller

U.S. Geological Survey, cmueller@usgs.gov

Follow this and additional works at: https://digitalcommons.unl.edu/usgsstaffpub

Part of the Earth Sciences Commons

Wheeler, Russell L. and Mueller, Charles S., "Central US earthquake catalog for hazard maps of Memphis, Tennessee" (2001). USGS Staff -- Published Research. 446.

https://digitalcommons.unl.edu/usgsstaffpub/446

This Article is brought to you for free and open access by the US Geological Survey at DigitalCommons@University of Nebraska - Lincoln. It has been accepted for inclusion in USGS Staff -- Published Research by an authorized administrator of DigitalCommons@University of Nebraska - Lincoln. 


\title{
Central US earthquake catalog for hazard maps of Memphis, Tennessee
}

\author{
Russell L. Wheeler*, Charles S. Mueller \\ US Geological Survey, P.O. Box 25046, MS 966, Lakewood, CO 80225, USA
}

\begin{abstract}
An updated version of the catalog that was used for the current national probabilistic seismic-hazard maps would suffice for production of large-scale hazard maps of the Memphis urban area. Deaggregation maps provide guidance as to the area that a catalog for calculating Memphis hazard should cover. For the future, the Nuttli and local network catalogs could be examined for earthquakes not presently included in the catalog. Additional work on aftershock removal might reduce hazard uncertainty. Graphs of decadal and annual earthquake rates suggest completeness at and above magnitude 3 for the last three or four decades. Any additional work on completeness should consider the effects of rapid, local population changes during the Nation's westward expansion. (C) 2001 Elsevier Science B.V. All rights reserved.
\end{abstract}

Keywords: Hazard; Earthquakes; Catalogs; Seismic risk; Memphis, Tennessee

\section{Introduction}

Preparation of the current national probabilistic seismic-hazard maps (Frankel et al., 1996, 1997) involved the creation of a composite earthquake catalog that includes the central and eastern US (CEUS; east of the Rocky Mountains) (Mueller et al., 1997). The current national maps are commonly referred to as 'the 1996 maps', after the distribution date of their review drafts. The composite CEUS catalog is a concatenation of existing catalogs. This report assesses the suitability of the composite catalog for making a planned folio of large-scale seismichazard maps of the Memphis urban area, and identifies catalog improvements that might be needed for the Memphis computations. The Memphis

\footnotetext{
* Corresponding author. Tel.: +1-303-273-8589; fax: +1-303273-8600.

E-mail address: wheeler@usgs.gov (R.L. Wheeler).
}

seismic-hazard maps are planned for completion in calendar years 2002 and 2003. This report was written by and for specialists in making seismic-hazard maps. For the benefit of others, Table 1 defines jargon.

Note that making a seismic hazard map requires more than a catalog. It also requires an attenuation relation appropriate for the map area. In addition, map making may require specification and justification of source zones, in order to compensate for a CEUS historical record that is short compared to recurrence intervals of large earthquakes. This report is restricted to catalogs.

Although this report focuses on the Memphis maps, we have occasionally cast our net more widely across the CEUS to report observations that might benefit planned preparation of other, smaller-scale hazard maps. For example, a folio of regional hazard maps will cover lat. $34-40^{\circ} \mathrm{N}$ and long. $85-95^{\circ} \mathrm{W}$ in the central US. Analysis for these maps will concentrate on modeling the response of the sediments that fill the 
Table 1

Definitions of magnitude symbols, catalog acronyms, and other jargon

\begin{tabular}{|c|c|}
\hline Term & Definition \\
\hline$M_{\mathrm{L}}$ & $\begin{array}{l}\text { The original Richter } \\
\text { magnitude, measured on a } \\
\text { specific type of seismograph } \\
\text { for earthquakes recorded in } \\
\text { southern California. }\end{array}$ \\
\hline$m_{\mathrm{b}}$ & $\begin{array}{l}\text { Body-wave magnitude, } \\
\text { measured on } \mathrm{P} \text { waves with } \\
\text { periods of } 1 \mathrm{~s} \text {. }\end{array}$ \\
\hline$M_{\mathrm{S}}$ & $\begin{array}{l}\text { Surface-wave magnitude, } \\
\text { measured on surface waves with } \\
\text { periods of } 20 \mathrm{~s} \text {. }\end{array}$ \\
\hline$m_{\mathrm{bLg}}$ & $\begin{array}{l}\text { An estimate of } m_{\mathrm{b}} \text {, measured on } \\
\mathrm{Lg} \text { waves with periods of } 1 \mathrm{~s} \text {. } \\
\text { Developed for use in the central } \\
\text { and eastern US. }\end{array}$ \\
\hline$M_{\mathrm{N}}$ & $\begin{array}{l}m_{\mathrm{bLg}}, \text { but calculated slightly } \\
\text { differently in Canada. }\end{array}$ \\
\hline$M_{\mathrm{d}}$ & $\begin{array}{l}\text { Duration magnitude, an estimate } \\
\text { of } m_{\mathrm{bLg}} \text { measured as the duration } \\
\text { of the earthquake vibrations as } \\
\text { they die out with time. }\end{array}$ \\
\hline$m_{\mathrm{Lg}}(10 \mathrm{~Hz})$ & $\begin{array}{l}\text { Magnitude measured on } \mathrm{Lg} \\
\text { waves with frequencies of } 10 \mathrm{~Hz} \\
\text { (periods of } 0.1 \mathrm{~s} \text { ). }\end{array}$ \\
\hline$m_{\mathrm{Lg}}(3 \mathrm{~Hz})$ & $\begin{array}{l}\text { Magnitude measured on } \mathrm{Lg} \\
\text { waves with frequencies of } 3 \mathrm{~Hz} \\
\text { (periods of } 0.3 \mathrm{~s} \text { ). }\end{array}$ \\
\hline $\mathbf{M}$ & $\begin{array}{l}\text { Moment magnitude, } \\
\text { proportional to the logarithm of } \\
\text { the seismic moment that was } \\
\text { released by an earthquake. This } \\
\text { is becoming the preferred } \\
\text { magnitude scale for most } \\
\text { applications. }\end{array}$ \\
\hline CNMSN catalog & $\begin{array}{l}\text { Earthquake catalog of the } \\
\text { Cooperative New Madrid } \\
\text { Seismic Network, which } \\
\text { currently monitors the New } \\
\text { Madrid seismic zone and its } \\
\text { surroundings. }\end{array}$ \\
\hline DNAG catalog & $\begin{array}{l}\text { Earthquake catalog for all of } \\
\text { North America, compiled for the } \\
\text { Decade of North America } \\
\text { project of the Geological } \\
\text { Society of America. The catalog } \\
\text { extends through 1985 (Engdahl } \\
\text { and Rinehart, 1988, 1991). }\end{array}$ \\
\hline Nuttli catalog & $\begin{array}{l}\text { Earthquake catalog for the } \\
\text { central US, compiled by Otto } \\
\text { Nuttli and covering 1810-1980 } \\
\text { (Nuttli, 1979). }\end{array}$ \\
\hline
\end{tabular}

Table 1 (continued)

\begin{tabular}{|c|c|}
\hline Term & Definition \\
\hline NCEER-91 catalog & $\begin{array}{l}\text { Earthquake catalog produced by } \\
\text { the National Center for } \\
\text { Earthquake Engineering } \\
\text { Research, and covering the } \\
\text { central and eastern US and } \\
\text { adjacent Canada into February, } \\
1985 \text { (Seeber and Armbruster, } \\
\text { 1991). }\end{array}$ \\
\hline USGS PDE catalog & $\begin{array}{l}\text { Earthquake catalog of the globe, } \\
\text { named Preliminary } \\
\text { Determination of Epicenters and } \\
\text { maintained by the USGS. }\end{array}$ \\
\hline USGS SRA catalog & $\begin{array}{l}\text { Earthquake catalog compiled by } \\
\text { C.W. Stover, B.G. Reagor, and } \\
\text { S.T. Algermissen of the USGS, } \\
\text { and covering the US through } \\
1986 \text { (Stover et al., 1984). }\end{array}$ \\
\hline USGS USHIS catalog & $\begin{array}{l}\text { Earthquake catalog of damaging } \\
\text { US earthquakes through } 1989 \\
\text { (Stover and Coffman, 1993). }\end{array}$ \\
\hline$b$-value & $\begin{array}{l}\text { A measure of the ratio of the } \\
\text { number of small earthquakes in } \\
\text { a stated area to the number of } \\
\text { large earthquakes. More } \\
\text { specifically, one of two fitted } \\
\text { constants in the Gutenberg- } \\
\text { Richter relation, } \log _{10} N(M)= \\
a-b M \text {, where } N(M) \text { is the } \\
\text { annual number of earthquakes of } \\
\text { magnitude } M \text { or larger. The } \\
\text { slope of a graph of this equation } \\
\text { is } b \text {, commonly approximately } \\
-1 \text {. }\end{array}$ \\
\hline
\end{tabular}

Mississippi embayment trough (R.B. Herrmann, written communs., 1999). In addition, updated versions of the 1996 national maps are planned for completion in 2001 (A.D. Frankel, oral communs., 1999).

\section{Needs of hazard mapping}

If asked to list the most important attributes of an earthquake catalog, makers of probabilistic hazard maps would probably list many of the same things that other seismologists would list. However, the two groups would be likely to assign different 
priorities to the attributes. Spatial uniformity of the magnitude scale throughout the catalog is of primary importance to hazard mapping, because one of the main purposes of a hazard map is to compare hazards at different places. Accurate magnitudes are important both for the large earthquakes that can cause damage, and for the smaller earthquakes near the minimum magnitude of earthquakes that are counted to determine earthquake rates for a hazard calculation. The smaller earthquakes are important because they are much more numerous. Therefore, if systematic magnitude errors move many of them above (or below) the minimum magnitude, $b$-values (Table 1) can be distorted by increasing (or decreasing) the numbers of earthquakes in the smallest-magnitude bins. For a single earthquake, magnitudes that are derived from the scales in use in the CEUS can vary by as much as a full unit, and differences of approximately $1 / 4$ of a unit are common between reports from different networks for the same earthquake measured on the same magnitude scale. For example, for earthquakes in southeastern Canada before 1930 , recently recalculated $M_{\mathrm{N}}$ values (Table 1 ) of the Canadian Geological Survey are systematically 0.4 units higher than the $m_{\mathrm{b}}$ values of the composite catalog used for the 1996 US hazard maps, values which were dominantly taken from the NCEER-91 catalog (Table 1) (Wheeler, unpubl. results). For another example, Seeber and Armbruster (1991) argued that small, shallow, pre-instrumental earthquakes that are characterized only by maximum intensity may have magnitudes that are systematically over-estimated.

Accurate and reproducible identification and removal of aftershocks, foreshocks, and duplicate entries are of similarly high importance, because dependent earthquakes and duplicates inflate seismicity rates where they occur but not elsewhere. The resulting spotty distortion of hazard tends to obscure the geographic differences in hazard. Duplicate entries can arise when an earthquake is reported by two different networks, which might use slightly different velocity models and location algorithms to produce slightly different origin times, locations, or magnitudes (M. Withers, oral commun., 1999). Duplicates can also result from failure to distinguish Julian from Gregorian dates, or local from Greenwich times, or to account for time zones or daylight savings time. Rarely, identical duplicate entries can be contributed inadvertently by the same network.

The determination of completeness dates is also important, although less so than a uniform magnitude scale or removal of dependent earthquakes and duplicate entries. Unrecognized areal differences in completeness distort the geographic distribution of hazard. The westward spread of CEUS population during the 1800s and early 1900s affected completeness. It is useful to assess completeness separately for several magnitude levels, including the minimum magnitude that is considered by the particular hazard algorithm being used. For the CEUS, the minimum magnitude is $m_{\mathrm{b}} 3.0$ for the 1996 maps (Frankel et al., 1996).

\section{The present catalog}

The 1996 maps used a western US catalog of moment magnitudes $\mathbf{M}$, and a central and eastern US catalog of body-wave magnitudes $m_{\mathrm{b}}$; the latter catalog is known informally by the name of its computer file, emb.cc (Mueller et al., 1997). Emb.cc contains 2738 earthquakes of $m_{\mathrm{b}} 3.0$ or larger that occurred from 1700 to June 16, 1995 in the CEUS, Rocky Mountains, Colorado Plateau, and southeastern Canada. The CEUS part of emb.cc we will refer to as the CEUS catalog. The CEUS catalog was derived from five preceding catalogs, and is dominated by the NCEER-91 catalog (Table 1; Seeber and Armbruster, 1991) through February 1985 and the USGS PDE afterwards. Smaller contributions are from the USGS USHIS catalog of Stover and Coffman (1993), the USGS SRA catalog of Stover et al. (1984), and the DNAG catalog. After concatenation and sorting by date, algorithms described by Mueller et al. (1997) eliminated duplicate entries and dependent earthquakes, and converted the various magnitude types to estimates of $m_{\mathrm{b}}$. The CEUS catalog and documentation may be downloaded from URL http://geohazards.cr.usgs.gov/eq/ as part of emb.cc. (This and all other URLs cited in this paper were correct as of December 19, 2000.)

We have not yet mentioned two well-known central US catalogs, those of Nuttli $(1974,1979)$ and the Cooperative New Madrid Seismic Network 
(CNMSN). They were incorporated into the CEUS catalog as follows. The Nuttli catalog spans approximately lat. $30-48^{\circ} \mathrm{N}$ and long. $80-104^{\circ} \mathrm{W}$, and the years 1810-1980. The Nuttli catalog from 1811 to 1975 was incorporated, through intermediate catalogs, into the NCEER-91 catalog (Seeber and Armbruster, 1991) and the SRA catalog (Stover et al., 1984), and thereby into the CEUS catalog. The CNMSN catalog spans approximately 36 square degrees, including the New Madrid and Wabash seismic zones and the southern Illinois basin, and the years 1974 to present. CNMSN records were not explicitly collected into the CEUS catalog, although probably many or most earthquakes of $m_{\mathrm{b}} 3.0$ or larger that were recorded by CNMSN have been reported to the PDE and, thereby, have been added to the CEUS catalog. Both the CNMSN and Nuttli catalogs can be downloaded from the World Wide Web (URLs http://folkworm.ceri.memphis.edu/catalogs/ html/cat_nm.html and http://www.eas.slu.edu/Earthquake_Center/earthquake_data.html, respectively). Therefore, whether their earthquakes have been fully incorporated into the CEUS catalog could be determined straightforwardly.

\section{Definition of catalog map area}

A hazard map for any part of the CEUS requires catalog coverage that extends hundreds of kilometers beyond the area to be mapped, because large CEUS earthquakes can cause long-period shaking that attenuates slowly with distance. A useful guide to the geographic extent of needed catalog coverage is the set of city-specific deaggregation maps at URL http://geohazards.cr.usgs.gov/eq/ (Harmsen et al., 1999). The deaggregation maps draw on data and calculations of the 1996 national hazard maps. Each deaggregation map is centered on a city, and shows the locations of the various earthquake sources that contribute to the total hazard at the city, the proportion of the total hazard that is attributable to each source, and the magnitude of the earthquakes at that source that cause hazard at the city. Each city is represented by a pair of deaggregation maps that show hazard from spectral accelerations of 0.2-s period, which comes mainly from medium-magnitude earthquakes at local sources, and 1.0-s period, which comes mainly from large earthquakes at both nearby and distant sources.

The deaggregation maps for Memphis show that most of the hazard comes from moment magnitude M 7-8 earthquakes in the New Madrid seismic zone, M 7 earthquakes in the Wabash seismic zone, and local earthquakes of M 5-6 within 100-150 km. Thus, an earthquake catalog from which to calculate Memphis hazard should cover these areas. This conclusion is supported by deaggregation maps for Cincinnati, Kansas City, Knoxville, Lexington, Nashville, and St Louis. Accordingly, a catalog for the Memphis maps might cover lat. $33-39^{\circ} \mathrm{N}$ and long. $87-93^{\circ} \mathrm{W}$.

Additional deaggregation maps could be used to estimate required catalog coverage for hazard maps of larger areas between the Appalachian and Rocky Mountains. For example, at Kansas City and farther west and north in the central US, local sources dominate the hazard except for 1.0-s contributions from the New Madrid source. The Meers fault contributes to hazard only in the southwestern part of the central US, as at Oklahoma City, Tulsa, and Dallas. Contributions from the Meers fault are much smaller at Topeka, Houston, and San Antonio, and are largely confined to 1.0-s hazard. The Eastern Tennessee seismic zone dominates hazard at Knoxville, atop the zone, but the contribution of the zone is small at Nashville and Lexington and negligible at Cincinnati and Birmingham. The M 7.3 characteristic earthquakes that Frankel et al. (1996) modeled at the Charleston source in South Carolina contribute moderately to the 1.0-s hazard at Knoxville, but negligibly to hazard in the central US, even at Nashville.

Future findings might require that a catalog for the Memphis maps cover an area larger than that deduced from existing deaggregation maps, which are constructed from hazard computed for uniform firmrock site conditions. For example, M. Withers (University of Memphis) observed "... that moderate earthquakes outside the (Mississippi) embayment generate large, low frequency, long duration surface waves within the embayment" (oral and written commun., 1999). The observation led Withers to suggest that a large, distant earthquake might excite basin response at or near Memphis. If further work substantiates this suggestion, the cataloged area could change. 


\section{Needed catalog improvements}

\subsection{Magnitudes}

The 1996 national hazard maps of Frankel et al. (1997) treat the three very large New Madrid earthquakes of 1811-1812 differently from the much more numerous, smaller earthquakes in the CEUS (Frankel et al. 1996). This paper deals with the latter, smaller earthquakes, and is not affected by the current, fading debate about the actual magnitudes of the three very large New Madrid earthquakes (Newman et al., 1999; Atkinson et al., 2000; Wheeler and Perkins, 2000).

Central US magnitude conventions are more or less uniform. Nuttli (1973b) instituted the use of $m_{\mathrm{bLg}}$. Measurements of the amplitudes of 1-s period Lg waves were used to calculate $m_{\mathrm{bLg}}$ as an estimate of $m_{\mathrm{b}}$ in the central US Most central US catalogs now list $m_{\mathrm{bLg}}$, either calculated directly, or estimated from (1) intensity data, (2) some amplitude other than that of 1$\mathrm{s}$ period $\mathrm{Lg}$, or (3) coda duration. However, the hazards community has moved to use of moment magnitudes, which indicates that the ideal, generalpurpose, central US catalog will use moment magnitude, M. Magnitude uncertainty will be minimized and precision maximized if $\mathbf{M}$ is calculated directly from seismograms, or estimated from intensity data, instead of converted from various other magnitudes such as $m_{\mathrm{bLg}}$.

The New Madrid seismic zone and environs have been monitored by one or more local networks since 1974, with varying areas of coverage. The two largest networks have merged to form the CNMSN. Before the merger, the two networks used duration magnitudes $M_{\mathrm{d}}$ (Table 1) to estimate $m_{\mathrm{bLg}}$ in the south (Chiu, 1993); and $m_{\mathrm{Lg}}(10 \mathrm{~Hz}), m_{\mathrm{Lg}}(3 \mathrm{~Hz})$, or $m_{\mathrm{bLg}}$, depending on earthquake location and signal period, in the north (Whittington and Herrmann, 1997). Now the CNMSN uses $M_{\mathrm{d}}$ unless an earthquake is large enough for the USGS National Earthquake Information Center to calculate $m_{\mathrm{bLg}}$ (M. Withers, oral commun., 1999).

The Nuttli catalog is dominated by $m_{\mathrm{bLg}}$ calculated in various ways for pre-instrumental earthquakes (Nuttli, 1979). For the few earthquakes large enough to have an isoseismal map with more than one isoseismal, the decrease of intensity with distance was used to calculate $m_{\mathrm{bLg}}$ (Nuttli, 1973a). For the more numerous earthquakes with defined felt areas, $m_{\mathrm{bLg}}$ was calculated from a second-degree polynomial in felt area (Nuttli and Zollweg, 1974). For the majority of the smaller earthquakes, only maximum intensity was available, and this was converted directly to $m_{\mathrm{bLg}}$ with a look-up table of unspecified origin (Nuttli, 1974). Absent an isoseismal map, if magnitudes from both the felt area and the maximum intensity were available, Nuttli (1979) used the larger.

The CNMSN and Nuttli catalogs are primary sources. The NCEER-91 catalog is partly a primary source for the entire CEUS through February 1985. In addition to compiling earthquakes from older catalogs, Seeber and Armbruster (1991) performed archival searches to discover many previously forgotten earthquakes and to increase the numbers of intensity reports for many catalogued earthquakes. Seeber and Armbruster (1991) also used the regression relations of Sibol et al. (1987) to convert numerous magnitude estimates from values that had been based only on maximum intensity to more accurate $m_{\mathrm{bLg}}$ estimates based on felt areas. Seeber and Armbruster's (1991) stated goal was analysis of earthquakes east of long. $87.5^{\circ} \mathrm{W}$ (east of long. $88.5^{\circ} \mathrm{W}$ in Mississippi). However, approximately one third of the earthquakes that were in the searchable digital catalog of NCEER-91 when catalog emb.cc (Section 3) was compiled lie farther west; on March 25, 1999, two were at long. $107^{\circ} \mathrm{W}$ (URL http://mceer.buffalo.edu/links/eqcatalogs.asp).

The CEUS catalog is entirely a secondary source, as explained earlier in Section 3. Magnitudes $M_{\mathrm{L}}, M_{\mathrm{N}}$, and $M_{\mathrm{d}}$ (Table 1), as well as estimates of $m_{\mathrm{b}}$ that were obtained from felt areas or maximum intensities, were all treated as $m_{\mathrm{b}} . M_{\mathrm{S}}$ and $\mathbf{M}$ were converted to $m_{\mathrm{b}}$ with piecewise-linear relations of the form $m_{\mathrm{b}}=a M+b$, where $a$ and $b$ are constants. Where multiple magnitudes were reported for a single earthquake, a weighted average was used to determine a single magnitude (Mueller et al., 1997).

\subsection{Dependent and duplicate earthquakes}

We are unaware of any generally accepted criteria for identifying foreshocks, aftershocks, or duplicate entries in the CEUS. Mueller et al. (1997) used the algorithm of Gardner and Knopoff (1974) to remove dependent events from emb.cc, including the CEUS 
catalog. The algorithm was developed for California earthquakes, and uses sliding windows in time and distance. A sliding 2-minute window was used to identify duplicate entries. One notable result was to remove all but one of the 1811-1812 New Madrid earthquakes, retaining only its last, largest, principal shock, that of February 7, 1812. This removal is appropriate for the methodology of Frankel et al. (1996), but users with other needs should bear this catalog property in mind.

Probably the most common contexts in which dependent earthquakes are identified are during special studies of individual aftershock sequences and during the course of routine network operations. Experience in either context can lead to qualitative rules of thumb, and some of these rules might even be quantified or formalized for local use. A poll of network operators in the CEUS should produce a valuable compendium of these rules of thumb. However, for compilation of a regional catalog for hazard analysis, thousands of earthquakes would need to be examined. Such a process would need to be performed with an algorithm, preferably designed from or trained on examples from the CEUS.

\subsection{Completeness}

Nuttli (1974) performed completeness tests and analyzed decadal stability for an early version of the Nuttli catalog, which covered approximately 26 square degrees in and near the New Madrid and Wabash seismic zones and southern Illinois. Nuttli concluded that the catalog for this fraction of the central US was probably complete since 1903 for $m_{\mathrm{bLg}} 3.4$ and larger, and since 1873 for $m_{\mathrm{bLg}} 4.4$ and larger. Mueller et al. (1997, p. 6-7) indicated that completeness at these magnitude levels may have been achieved considerably more recently for the entire CEUS taken as a whole. These results indicate that current completeness tests are needed for the comparatively active core of the central US, and separately for the comparatively less active majority of the central US. In addition, the rapid local population changes during the Nation's westward expansion likely produced rapid, local variations in completeness dates and magnitudes.

\subsection{Seismicity rates}

Annual or decadal rates of earthquakes above a specified magnitude cannot be calculated accurately until a map area is chosen and duplicate and dependent earthquakes are deleted. However, to calculate illustrative approximations of the rates that might be expected, we used the CEUS catalog to count decadal rates of $m_{\mathrm{b}} 3.0$ and greater for three nested map areas (Fig. 1). We make the common assumption that, averaged over the areas shown in Fig. 1, seismicity rates are more or less stationary through time. This assumption could be wrong in either direction, so that future seismicity could be greater or less than historical seismicity. Testing alternative hypotheses and assumptions involves numerous potential research topics, but for catalog purposes, and in the absence of clear evidence against regional stationarity in the CEUS, stationarity is the simplest assumption.

First, the area covered by the Nuttli catalog is approximately lat. $30-50^{\circ} \mathrm{N}$ and long. $75-105^{\circ} \mathrm{W}$ (600 square degrees, or approximately $5645000 \mathrm{~km}^{2}$ ). We clipped the CEUS catalog to these boundaries and grouped the resulting 1742 earthquakes by decade of occurrence. The CEUS catalog extends only through June 16, 1995. Accordingly, we simulated a complete final decade by multiplying the number of earthquakes listed for the first 5.5 years of the 1990 s by $10 / 5.5=1.82$.

Second, we contracted the map area to lat. 33$45^{\circ} \mathrm{N}$ and long. $83-100^{\circ} \mathrm{W}$ (204 square degrees, or approximately $1952000 \mathrm{~km}^{2}$ ), in order to (1) restrict the area to the central US and exclude most of the seismotectonically distinct Appalachians and Charleston, South Carolina area (Wheeler, 1995), and (2) exclude the nearly aseismic Gulf Coast region. Clipping the catalog of the previous paragraph to these boundaries left 922 earthquakes of $m_{\mathrm{b}} 3.0$ or larger. As for the larger map area, we collected them into decades and adjusted the last decadal count.

Third, the deaggregation maps indicate that hazard at Memphis likely would be dominated by seismicity in the smaller, generally more active area of lat. $33-39^{\circ} \mathrm{N}$ and long. $87-93^{\circ} \mathrm{W}$ (see Section 4; 36 square degrees, or approximately $359000 \mathrm{~km}^{2}$ ). We clipped the catalog of the preceding paragraph to 


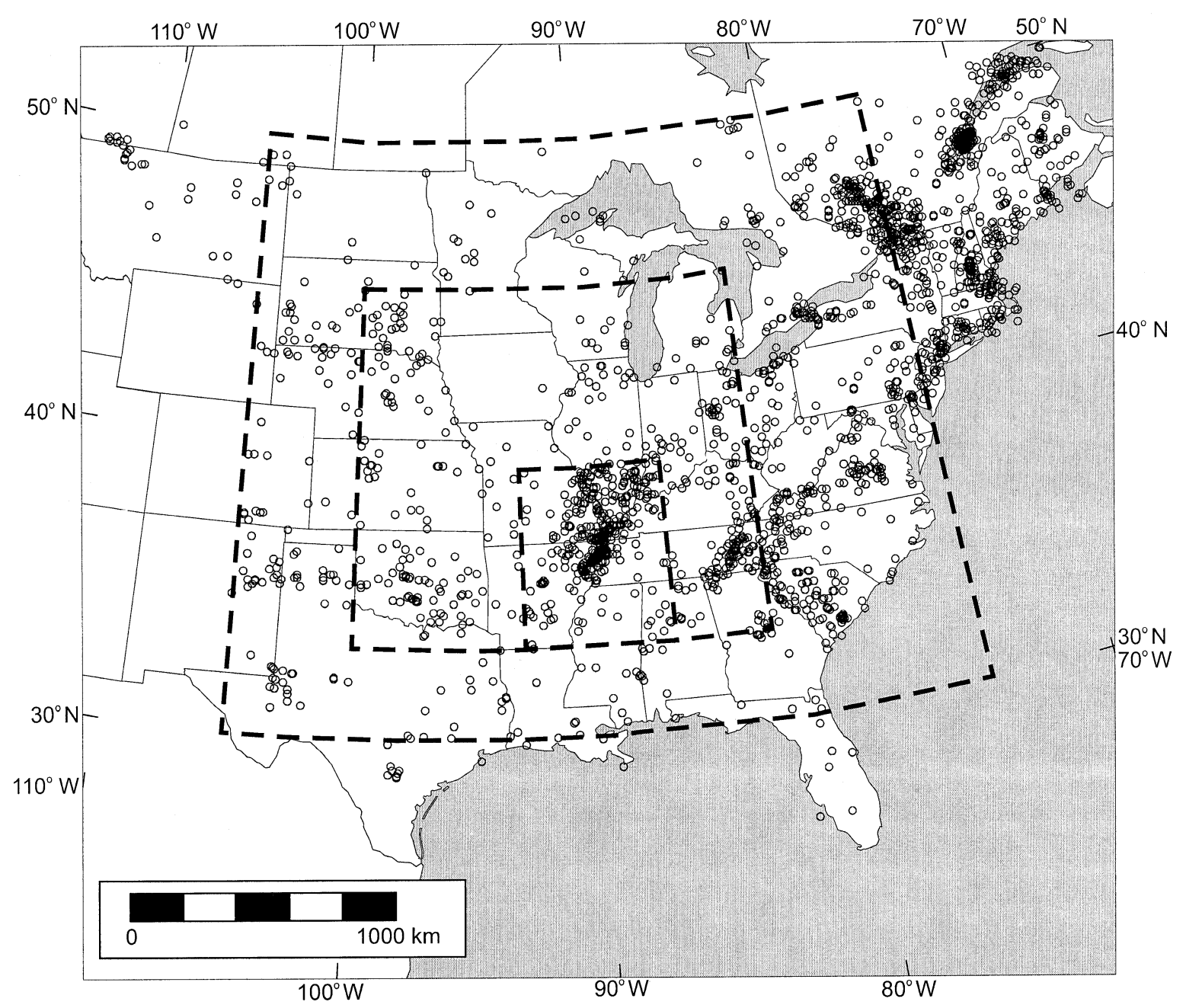

Fig. 1. Map of the central and eastern United States, showing epicenters (circles) of the earthquakes in the catalog that was used for the national probabilistic seismic-hazard maps of Frankel et al. $(1996,1997)$. Three dashed nested rectangles show map areas that are discussed in the text.

these boundaries, which left 505 earthquakes before adjusting the last decadal count.

Graphs of the numbers of earthquakes per decade for these three test areas show a recent break in the steady rise recorded since the Great Depression and World War II (Fig. 2). Perhaps the break marks the beginning of a more or less steady rate of recorded earthquakes. The break hints that earthquakes as small as $m_{\mathrm{b}} 3.0$ might be completely sampled over the most recent three or four decades, at least for the largest and smallest test area. However, this hint might be an artifact of our choice to start each decade with a year ending in zero. Accordingly, we regrouped the same data into decades that start with years ending in five, and compared the resulting graph (not shown here) to Fig. 2. The hint of completeness over the last three or four decades does not appear to be an artifact of our choice of decadal starting year. As a further test of recent completeness, we recast the twentieth-century data of Fig. 2 into annual rates so we could examine more intervals than the last three or four. Fig. 3 supports the suggestion of completeness since the 1960 s or 1970s. Annual rates since the early 1960s for the largest and smallest areas appear to oscillate about a higher mean than obtained before 1960. Thus, the record for the entire CEUS except 


\section{Decadal rates, 1750-1999}

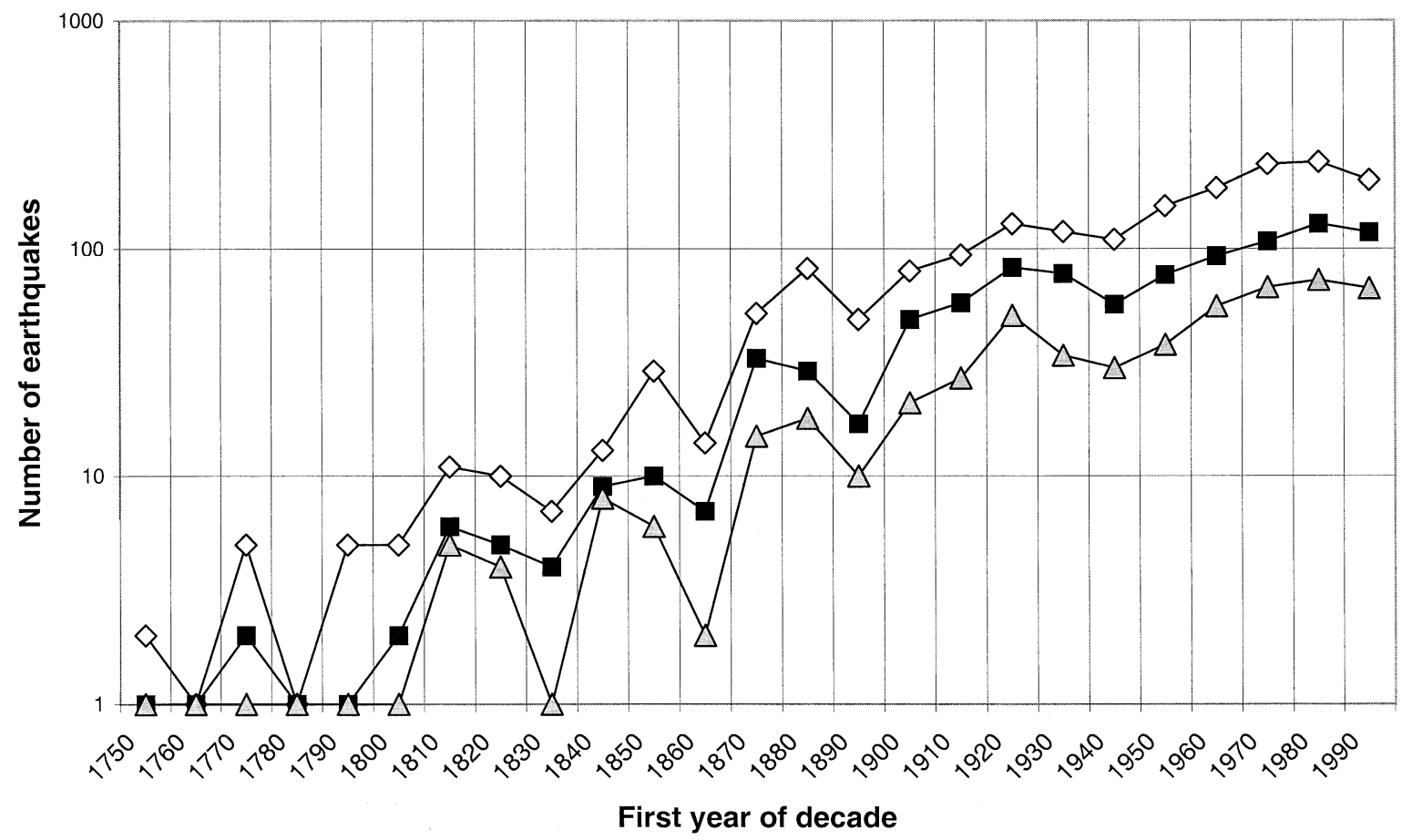

Fig. 2. Logarithmic decadal rates of central US earthquakes of magnitude $m_{\mathrm{b}} 3.0$ and larger, for decades beginning in years ending in zero. Source is the central and eastern US (CEUS) catalog, as described in text. The three graphs show, from top to bottom, rates from three successively smaller, nested map areas that are defined in the text and shown in Fig. 1. The bottom curve of shaded triangles shows rates for the map area suggested for calculating hazard at Memphis.

the Northeast (Fig. 1), as well as that for the Memphis area, might be complete for the past three or four decades at $m_{\mathrm{b}} 3.0$ and above.

For the three nested areas described in this section and shown in Fig. 1, mean annual rates of $m_{\mathrm{b}} 3.0$ and greater are higher after 1963 or 1964 than before (Fig. 3). The mean rates from 1965 to 1995 for the successively smaller and successively more active areas are $0.04,0.06$, and 0.19 earthquakes per year per $10000 \mathrm{~km}^{2}$. A more complete analysis, including completeness tests, would be appropriate after the steps listed later in Section 7 have been completed.

\subsection{Locations}

It is unclear how epicentral uncertainty varies with magnitude and with the year of the earthquake. If the smoothed seismicity approach of Frankel (1995) is to be used for the Memphis maps, then smoothing parameters must be chosen. Knowledge of the variations in epicentral uncertainty could affect the choice of smoothing parameters.

The variations could be directly characterized for the period of network operation by regressing measures of location uncertainty, which are calculated by standard earthquake location programs, on year or earthquake magnitude, or by plotting the uncertainty measures on a graph of year versus magnitude. However, these measures of location uncertainty record analytical uncertainty, and any other components of uncertainty might need to be evaluated differently, perhaps with calculations that use station spacings and velocity models. For example, A.C. Tarr calculated epicentral confidence ellipses for hypothetical events that were located at $0.5^{\circ}$ intervals across Virginia, using the network configuration as 


\section{Annual rates, 1900-1995}

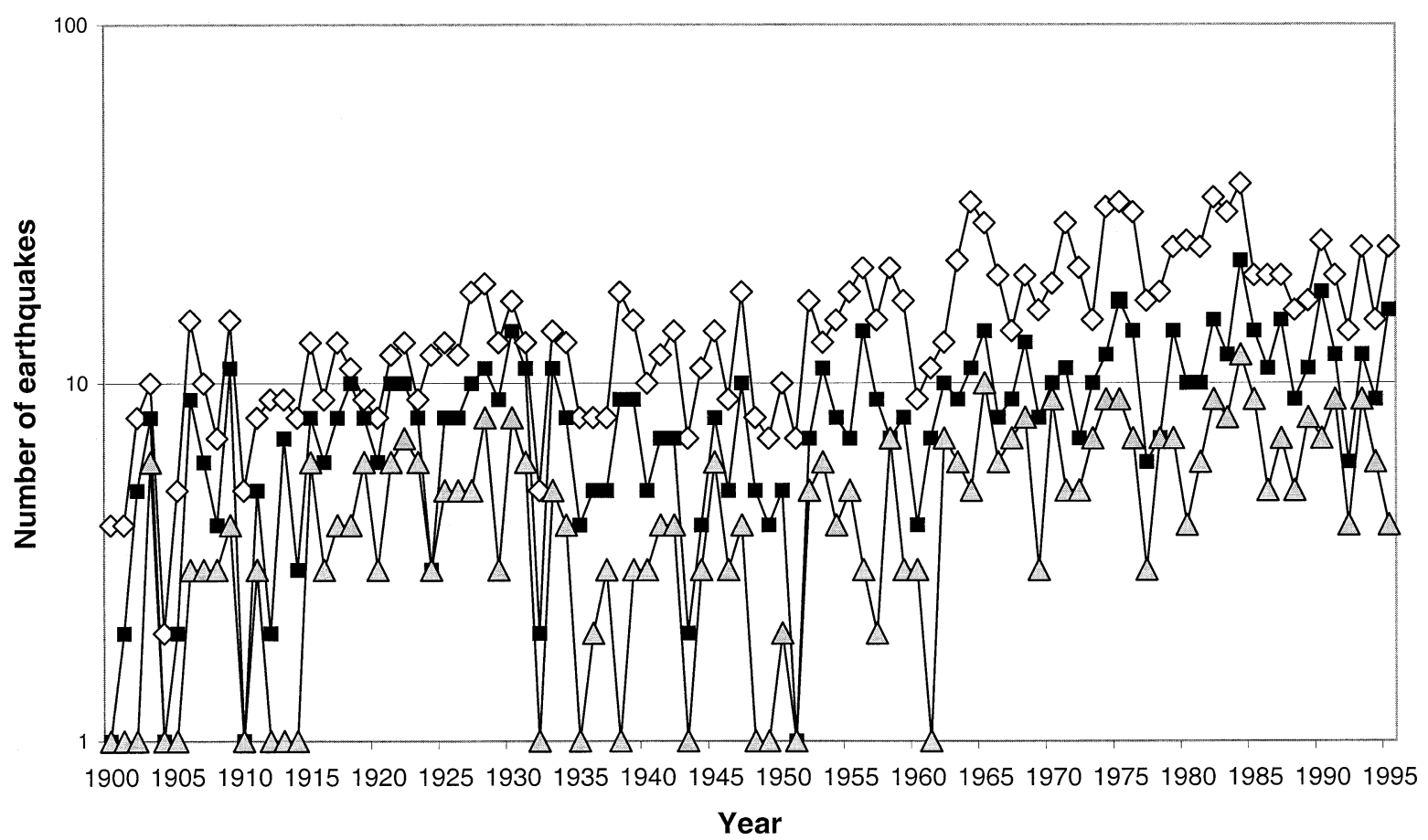

Fig. 3. Same as Fig. 2, except that graph shows annual rates for 1900 and later.

it existed in the late 1970s (Figs. 6 and 7 of Bollinger and Wheeler, 1988).

Alternatively, total uncertainty of epicenters derived from intensity data could be crudely characterized by measuring distances between macroseismic and instrumental epicenters for all earthquakes that have both. For example, Rhea and Wheeler (1996) applied this approach to five damaging earthquakes that occurred from 1958 to 1987 in the lower Wabash Valley near the IllinoisIndiana border. They found that macroseismic and instrumental epicenters differed by $4-31 \mathrm{~km}$. Yet another possible approach would be to take repeated small samples of the intensity reports from a wellreported instrumental earthquake and to compare the macroseismic epicenter from each sample to the instrumental epicenter. The effect of magnitude on macroseismic epicenters could be examined by applying this approach to instrumental earthquakes of a range of magnitudes. The effect of the year in which an earthquake occurred might be simulated by taking successively smaller samples with successively greater geographic scatter, to simulate the successively sparser intensity reports of successively older earthquakes. These considerations apply, whether epicenters are estimated by contouring intensity values plotted on a map (e.g. Stover and Coffman, 1993), or calculated directly from the intensity values and locations themselves (Bakun and Wentworth, 1997; A.C. Johnston, oral commun., 2000, as summarized by Wheeler and Perkins, 2000, p. 8).

\section{Work underway}

A.C. Johnston (University of Memphis) and colleagues plan to produce a fully documented, Webbased, searchable, moment-magnitude catalog for the 20 states between North Dakota, Texas, Alabama, and Ohio, inclusive (URL http://mae.ce.uiuc.edu/ TaskStatements/SG-7.htm). The catalog will span 
the historical and instrumental periods and extend down to the felt threshold at or below magnitude 3.0. Final results are anticipated for calendar year 2002. In addition, in an independent archival search spanning calendar years 1999 and 2000, L. Seeber, J. Armbruster, and A. Metzger are discovering many previously forgotten or never recognized CEUS earthquakes, improving felt-area estimates for numerous known earthquakes, and estimating moment magnitudes from felt areas (Armbruster et al., 1998; Metzger et al., 1998; L. Seeber, written commun., 1999). These two coordinated efforts should result in a uniform, documented, moment-magnitude catalog for the central US, perhaps in time for use in making the Memphis maps.

\section{Conclusions and recommendations}

An updated CEUS catalog could serve as a catalog for the Memphis maps, after some additional work. If the moment-magnitude catalog being prepared by A.C. Johnston and colleagues is ready in time, it should be used instead of the CEUS catalog.

Additional work, while not necessary to make a Memphis map, could lead to reduced uncertainty in future editions. The complete Nuttli and CNMSN catalogs should be examined for earthquakes that are not presently in the CEUS catalog. Aftershocks could be more precisely identified and removed, perhaps by using existing clustering algorithms that have been calibrated or trained on CEUS earthquake sequences. Completeness has been only roughly evaluated for the part of the CEUS that would affect hazard at Memphis. Estimation of completeness dates and magnitudes should consider the effects of rapid population changes during the Nation's westward expansion.

\section{Acknowledgements}

We have benefited from guidance by and discussions with A.D. Frankel, J.S. Gomberg, R.B. Herrmann, A.C. Johnston, A.G. Metzger, D.M. Perkins, Leonardo Seeber, and M.M. Withers. The manuscript was improved by the suggestions of J.G. Armbruster, Gomberg, Johnston, L. Seeber, and Withers.

\section{References}

Armbruster, J.G., Seeber, L., Metzger, A.G., 1998. 240 new historical mainshocks in eastern North America from reports in contemporary newspapers (abs.). EOS, Transactions of the American Geophysical Union 79 (Suppl. 17), S340.

Atkinson, G., Bakun, B., Bodin, P., Boore, D., Cramer, C., Frankel, A., Gasperini, P., Gomberg, J., Hanks, T., Herrmann, B., Hough, S., Johnston, A., Kenner, S., Langston, C., Linker, M., Mayne, P., Petersen, M., Powell, C., Prescott, W., Schweig, E., Segall, P., Stein, S, Stuart, B, Tuttle, M, Van Arsdale, R., 2000. Reassessing the New Madrid seismic zone. EOS, Transactions of the American Geophysical Union 81 (35), 397, pp. 402-403.

Bakun, W.H., Wentworth, C.M., 1997. Estimating earthquake location and magnitude from seismic intensity data. Bulletin of the Seismological Society of America 87, 1502-1521.

Bollinger, G.A., Wheeler, R.L., 1988. The Giles County, Virginia, seismic zone - seismological results and geological interpretations. US Geological Professional Paper 1355.

Chiu, S.C. (Ed.), 1993. CERI Quarterly Seismological Bulletin, 13 (4), October-December, 1992. Memphis State University Center for Earthquake Research and Information, Memphis, TN, p. 25.

Engdahl, E.R., Rinehart, W.A., 1988. Seismicity Map of North America. Geological Society of America, Boulder, Colorado, 4 sheets, scale 1:5,000,000.

Engdahl, E.R., Rinehart, W.A., 1991. Seismicity map of North America project. In: Slemmons, D.B., Engdahl, E.R., Zoback, M.D., Blackwell, D.D. (Eds.). Neotectonics of North America, Decade Map vol. 1. Geological Society of America, Boulder, Colorado, pp. 21-27.

Frankel, A., 1995. Mapping seismic hazard in the central and eastern United States. Seismological Research Letters 66 (4), $8-21$.

Frankel, A., Mueller, C., Barnhard, T., Perkins, D., Leyendecker, E.V., Dickman, N., Hanson, S., Hopper, M., 1996. National seismic-hazard maps — documentation June 1996. US Geological Survey Open-File Report 96-532, p. 70.

Frankel, A., Mueller, C., Barnhard, T., Perkins, D., Leyendecker, E.V., Dickman, N., Hanson, S., Hopper, M., 1997. Seismichazard maps for the conterminous United States. US Geological Survey Open-File Report 97-131, 12 colored sheets, scale 1:7,000,000.

Gardner, J.K., Knopoff, L., 1974. Is the sequence of earthquakes in southern California, with aftershocks removed, Poissonian? Bulletin of the Seismological Society of America 64, 13631367.

Harmsen, S., Perkins, D., Frankel, A., 1999. Deaggregation of probabilistic ground motions in the central and eastern United States. Bulletin of the Seismological Society of America 89, $1-13$.

Metzger, A.G., Armbruster, J.G., Seeber, L., 1998. New earthquakes from old newspapers - improving the historical record (abs.). EOS, Transactions of the American Geophysical Union 79 (Suppl. 17), S340. 
Mueller, C., Hopper, M., Frankel, A., 1997. Preparation of earthquake catalogs for the national seismic-hazard maps contiguous 48 States. US Geological Survey Open-File Report 97-464, p. 36.

Newman, A., Stein, S., Weber, J., Engeln, J., Mao, A., Dixon, T., 1999. Slow deformation and lower seismic hazard at the New Madrid seismic zone. Science 284, 619-621.

Nuttli, O.W., 1973a. The Mississippi Valley earthquakes of 1811 and 1812 - intensities, ground motion, and magnitudes. Bulletin of the Seismological Society of America 63, 227-248.

Nuttli, O.W., 1973b. Seismic wave attenuation and magnitude relations for eastern North America. Journal of Geophysical Research 78 (5), 876-885.

Nuttli, O.W., 1974. Magnitude-recurrence relations for central Mississippi Valley earthquakes. Bulletin of the Seismological Society of America 64, 1189-1207.

Nuttli, O.W., 1979. Seismicity of the central United States. Geology in the Siting of Nuclear Power Plants, In: Hatheway, A.W., McClure Jr, C.R. (Eds.). Geological Society of America Reviews in Engineering Geology 14, 67-93.

Nuttli, O.W., Zollweg, J.E., 1974. The relation between felt area and magnitude for central United States earthquakes. Bulletin of the Seismological Society of America 64, 73-85.

Rhea, S., Wheeler, R.L., 1996. Map showing seismicity in the vicinity of the lower Wabash Valley, Illinois, Indiana, and Kentucky. US Geological Survey Geologic Investigations Map I-2583-A, scale 1:250,000, 14 pp., pamphlet.
Seeber, L., Armbruster, J.G., 1991. NCEER-91 Earthquake Catalog. National Center for Earthquake Engineering Research, Buffalo, New York, p. 110.

Sibol, M.S., Bollinger, G.A., Birch, J.B., 1987. Estimation of magnitudes in central and eastern North America using intensity and felt area. Bulletin of the Seismological Society of America 77, 1635-1654.

Stover, C.W., Coffman, J.L., 1993. Seismicity of the United States, 1568-1989 (revised). US Geological Survey Professional Paper 1527,418 p.

Stover, C.W., Reagor, B.G., Algermissen, S.T., 1984. United States earthquake data file. US Geological Survey Open-File Report, 84-225, p. 123.

Wheeler, R.L., 1995. Earthquakes and the cratonward limit of Iapetan faulting in eastern North America. Geology 23, 105-108.

Wheeler, R.L., Perkins, D.M., 2000. Research, methodology, and applications of probabilistic seismic-hazard mapping of the central and eastern United States - minutes of a workshop on 13-14 June, 2000, at Saint Louis University. US Geological Survey Open-File Report 00-0390, p. 18.

Whittington, M., Herrmann, R., 1997. Cooperative New Madrid Seismic Network Earthquake Bulletin, 87 (1 January-31 December, 1996). Saint Louis University Department of Earth and Atmospheric Sciences, Saint Louis, Missouri, p. 38. 